\section{談話室 (海外研究体験記)}

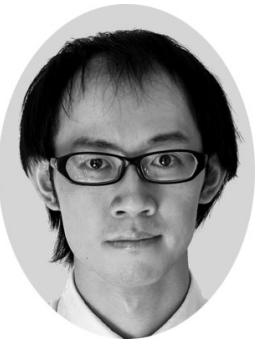

ハンブルグでの研究と生活

\section{ードイツと日本の違い一}

山崎 詩 郎

大阪大学産業科学研究所

恶 567-0047 大阪府茨木市美穂ヶ丘 8-1

(2014 年 6 月 17 日受理)

\section{Research and Life in Hamburg -Differences between Germany and Japan-}

Shiro YAMAZAKI

Institute of Scientific and Industrial Research, Osaka University, 8-1 Mihogaoka, Ibaraki, Osaka 567-0047

(Received June 17, 2014)

あの憧れの MIT で語学学校がある。そう聞いて真っ 先に参加を決意したのが私の海外デビューだった。多感 な 19 歳の夏のことである。そこで大きな発見をした。 海外で英語で話しているといつもより自分が出せるとい うことだ。そうして同じく海外留学を目指す多くの友達 ができた。わずか 3 週間弱だったが留学が人生を変える ということを身をもって体験した私は，その後もその鮮 烈な経験が原動力となり, 海外での研究や生活に強い憧 れを持つようになった。

大学院から留学しょうと夢見ていたときもあったが, 英語を随一の苦手科目としていた私には実力的に無理で あった。結局, 博士課程は東京大学理学部物理学科の長 谷川修司先生のところで押世話になった。テーマは 4 端 子プローブを用いた原子一層の電気伝導である。研究室 には，フランス，中国，韓国，ロシアなど海外からの PD が多く, また国際学会や個人旅行を通して 20 か国 以上を訪問するなど, 日本にいながら比較的国際的な経 験のできる環境に恵まれていた。また, 最初の PDのと きにお世話になった東大物性研の長谷川幸雄先生は自身 が IBM での海外研究経験があり, よく海外の研究室に 相互訪問するなど積極的に海外経験をさせてくださっ た。ここでは走查トンネル顕微鏡を用いた研究を行って いた。このような国際色豊かな環境から，一度は海外で

E-mail : yamazaki@afm.eei.eng.osaka-u.ac.jp
研究し彼らの研究とそのスタイルを肌で感じてこようと 決意した。それから 10 か所程度の候補をあげ, その中 から最も興味のあった走查トンネル顕微鏡の分野で世界 のトップランナーであるハンブルグ大学の Roland Wiesendanger 教授に CV と呼ばれる英語版の履歴書をダメ 元で送ってみた。すると「4月から来ないか？」。即効 で OK の返事をいただいた。なんと私の博士と PD の経 験を総結集したかのような新プロジェクトがちょうど始 まったらしい。普通は面接に行って合否が決まるものだ が, 需要と供給がピッタリ一致していたためそれも例外 的に不要だった。これは運命だと思って, この研究室に 行くことを決めた。ずっと憧れだった海外 “留学”があ らぬ形で現実になった。

ハンブルグ空港の入国ゲートをくぐると「Shiro」と 書かれたプラカードを持った院生トビーが立っていた。 ここから私のドイッでの 2 年 9 か月の海外研究が始まっ た。研究室メンバーは国際色豊かで 50 名ほどおり, ド イッ, フランス, スペイン, ポーランド, 中国, ロシ ア, 中東各国から優秀な研究者が集まっていた。特に扔 世話になった方々を写真（Fig. 1) で紹介する。グルー プのボスである Roland Wiesendanger 教授は巨大グルー プを統括する強いリーダーシップと一人一人に気を配る 優しさを兼齐えた素晴らしきリーダであった。私の属 するサブグループのリーダーはオシーである。オシーは 素晴らしい人格者で私のドイッでの父とも呼べる存在と なり何でも親切に教えてくれた。一年早く着任していた 先輩の吉田さんは研究面だけではなく, 生活面でも精神 面でも支えとなった1)。

最初の数か月，私はまだまだお客様という感じだっ

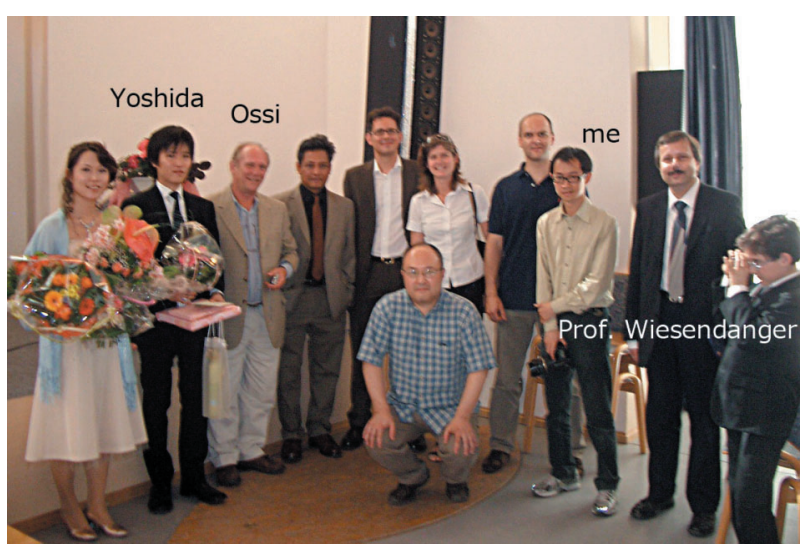

Fig. 1. (color online). Yoshida, Ossi, me, Prof. Wiesendanger and coworkers at Yoshida's engagement ceremony. 
た。実験が始まると意見が対立することもあったが，卜 ビーが自信満々に強く主張するので，おかしいと思って いても簡単に折れてしまった。その結果, 実験が失敗す ることも多かった。するとトビーは「もし正しいと思う 意見があるなら言っていいんだよ」。それから私も自分 が正しいと思っていることを簡単には曲げずに主張する ようになり，実験も二人三脚でよりうまくいくようにな った。滞在前半の私に課せられたテーマは, 4 端子 STM とスピン偏極 STM を結合させて, 4 端子スピン偏 極 STM を作れというものだった。この過程で研究室の 真骨頂であるスピン偏極 STM についての基礎を一通り 学ぶことができた。

「どうしてこの研究室はあんなに成果が出るのか?」 よく研究者から聞かれる質問だ。確かにWiesendanger 研究室は Nature や Science を連発し, 毎月のように PRL 以上のパブリケーションに対するパーティーが開かれて いた。サブグループミーティングに参加することでその 仕組みを少し垣間見ることができた。彼らは初めから Nature や Science をターゲットとして思った通りの実験 や結果をデザインしていた。ひとたび害験が上手くいけ ば測定は半自動的に行って, 18 時過ぎにはほとんどの ドイッ人は帰宅していた。日本では職人芸や時間をかけ て実験することが評価され, 論文は結果が出てきてから 考えるという傾向がある。真逆だった。彼らはその日の スケジュールから仕事分担まで生活のあらゆることをデ ザインしていた。ドイツの整然とした公園や町並みなど を見るとそれがよくわかる。

最初の一年半を終え, コントラクト (雇用契約) の更 新時期がやってきた。ここまで目立った成果のなかった 私は Wiesendanger 教授から「結果がなければコントラ クトの延長はない」とあっさり言われ㷌国を覚悟した。 そこからハッと目が覚めて, ここではガツガッしなけれ ばクビになってしまうと気づいた。帰国前の最後のミー ティングでこれまでの結果の総まとめを一時間かけて本 気で発表した。するとその日の夕方にボスからメールが あった。「もう一年滞在を延長するか？ 来てくれ」。ド イッでは結果と雇用がより直結していると思った。

滞在後半はナノ構造を有したグラフェンの 4 端子走查 トンネルポテンシオメトリーによる局所的電気伝導測定 の研究にスイッチした。前半は研究室の技術を学ぶこと が中心であったが, 後半はこちらの得意技術を輸出しな ければならない。このテーマについて詳しいのは私一人 であったため, これまでのように研究室のメンバーに頼 ることはできない。自らがプロジェクトを主導して実験 計画から実験装置の立ち上げ試料集めまですべてを行う
必要があった。時にはドイツ国内, シンガポールや日本 の研究室を複数訪問した。海外で新プロジェクトの中心 となって自主的に研究を進める経験は大変であったが得 るものも大きかった。

研究以外の生活面も海外滞在の貴重な経験だ。ドイッ に居たと話すと必ず聞かれるのが,「ドイツ語は喋れ る?」だ。語学が苦手だった私はドイツ語は 20 単語も 覚えることができなかった。数字も大学の最寄駅で買う パンの個数を伝えるためにアインからッヴァイまで覚え ただけであった。それでもハンブルグでは街中で英語が 普通に通じるため大きな不自由はなかった。もう一つよ く聞かれるのが「毎日ソーセージ（またはビール）？」 だ。ドイツ料理もおいしいものは数多くあるが, ドイツ 人の友人に勧められたのはイタリア料理店であった。イ タリア, トルコ, 中華料理には毎週のように打世話にな った。3 年弱通い詰めた中華料理屋では麻婆豆腐を毎週 注文し，私が店に入るだけで㕌房の奥からまーぽーどう ふ（が来た）と聞こえてくるまでになった。

旅行好きな人にとって掠きの朗報がある。ドイッでは 研究室でもほとんどの人が有給休棂を使い切って大体一 か月半の長期休㗇を取る。旅行と写真を最大の趣味とし ていた私はこの機会を逃さず，モロッコ，グアテマラ， エチオピアなどを巡る機会を得た。エチオピアでは小学 校教育を取材し, 幸い JICA のグローバル教育コンクー ルで入選することができた。また，週末だけでヨーロッ パ内の祭りにピンポイント参加できるのも滞在者ならで はである。ケルンカーニバル, ゲイパレード, クリスマ スマーケット，また家族と行ったオクトーバーフェスト はシャッターチャンスに事欠かなかった。

日本に帰ってきてから最初の一年は, とにかく帰って きたなという一年で, しばらくは日本での “異国”体験 を楽しみつつ, ドイッと日本の違いをいろんな人に話し た。二年目で自身の変化に気付いた。積極性が上がった のか, 渡航前より人間関係の交流がぐっと広がったの だ。海外に滞在すると日本と海外の良いところ悪いとこ ろが見えてくる。どちらが良いということではなく，こ ういう違いのふり幅が自分の頭の中にできたことが今後 の人生でもきっと役に立つはずだ。もし海外での研究滞 在を迷っている人がいたら, 思い切って行ってみること を勧める。私も19歳の夏に思い切って海外に行って本 当に良かったと思っている。

\section{文献}

1) 吉田靖雄 : 表面科学 33, 308 (2012). 